\title{
The Frontier of Remedies: A Call for Exploration ${ }^{\circ}$
}

\author{
Frank M. Coffin $\dagger$
}

For someone on a boat at sea it is nearly impossible to sense whether he is cresting a rising or falling tide, a monthly or seasonal high tide, or an historic advance of waters from the melting icecaps. I have the feeling that in the law of remedies for institutional violations of important constitutional rights we may be swept up in an historic sea change of which we are only dimly and imperfectly aware.

Five Sea Changes: $1940-1970$

Our hindsight in perceiving such matters is much more acute. We can identify, for example, a number of major turning points in the law in the last four decades. The first, largely taking place in the 1940's, was the full scale creation of administrative law, a vast area of innovation that involved the courts in new fields of substance and novel kinds of procedure and decisionmaking structures. A second major turning point began in the 1950's with what I term the first stage of the Civil Rights Revolution, the pioneering desegregation cases. A third development that occurred during the 1950's and 1960's was the Warren Court's concerted defense of civil liberties. A fourth development, one beginning in the late 1960's, was the reemergence of the Civil Rights Revolution. Cases in this period ranged far beyond school desegregation and invoked the long unused weapon of the Reconstruction Era, section 1983 of title 42 of the Umited States Code, to vindicate hitherto unasserted rights. Then in the 1970's we may point to the plethora (alnost fifty) of new people-oriented federal statutes-consumer, health, safety, antidiscrimination, environmental, welfare - as adding up to an impressive statutory bill of rights, the enforcement of which Congress has entrusted to the courts. With the exception of administrative law, all of these novements have involved substantive law reform. They all

(c) Copyright 1979, Frank M. Coffin. This Article is based on an address presented at Boalt Hall School of Law, University of California at Berkeley, February 28, 1979.

$\dagger$ Chief Judge of the United States Court of Appeals for the First Circuit. A.B. 1940, Bates College; 1.A. 1943, LL.B. 1947, Harvard University; Hon. LL.D. 1959, Bates College; Hon. LL.D. 1967, University of Maine, Hon. LL.D. 1969, Bowdoin College; Hon. LL.D. 1975, Colby College. 
contemplate that courts will continue to act in the same way they traditionally have acted.

Another development in the 1970's, the significance of which we are only beginning to apprehend, is a third stage of the Civil Rights Revolution. Unlike most of the earher "sea changes" we have noted, this last development calls on judges to handle a "case" differently, to frame and review orders differently from the patterns and precepts of their traditional role models. More than this, the new wave of civil rights litigation, with its stress on remedies, thrusts judges and courts into areas of conduct that he beyond what conventionally has been accepted as "judicial". All of this leads mevitably to probing questions: Is this developnient likely to continue? Is this a proper area for the judiciary? If judges must do this kind of nontraditional work, are thcre new standards, practices, and institutional devices that might be engrafted on the system?

\section{$\Pi$}

\section{Two Tales of a City}

Before we indulge in generalities, it may be useful to describe the tortuous courses-of two contemporary "new unodel" lawsuits, each of which sheds its own light on the problens and choices facing the litigants and the courts. One illustrates all three phases that I identify in the new wave of civil rights litigation; the other stopped at Phase Two. Under my conceptual frainework, Phase One is centered on the traditional determination of liability. Phase Two is characterized by the traditional judicial response of waiting and hoping for defendants to correct the probleins in response to the court order, perhaps with the additional prod of some jawboning and threats of future court action. Phase Three sees the court taking nontraditional and extraordinary actions in the face of defendants' inaction as it imposes and administers a solution.

The first case is the suit brought by black children and their parents to desegregate the public schools of Boston. Begun in 1972, it now claims as parties the plaintiff class, the school teachers' union, the Hoine and School Association, the state board of education, the Mayor of Boston, the defendant School Cominittee, with a number of amici. Phase One of the hitigation concerned only the issue of hability. While the evidentiary data were often complex, dehberation and decision both by the district court and our own reviewing court were traditional exercises. The district court issued a lengthy opinion, making findings of fact, applying Supreme Court and other precedents, and drawing conclusions of law to support its ultimate conclusion that intentional 
segregation (a dual school system) had been the policy of Boston scliool officials. $^{1}$

Our task in review, while a challenging one, lay well within comfortable boundaries. Where findings of fact were challenged, we went to the underlying exhibits or testimony to see if there was sufficient support. And in passing on sufficiency we would defer to the trial judge if testimony was in conflict; he, after all, had heard the witnesses and in general was closest to the matter. If the trial court's interpretation of the law were challenged, we did what we always have done-we determined whether the court's opinion accorded with our understanding of the governing precedent. ${ }^{2}$

With liability affirmed and certiorari denied by the Supreme Court, the district court then entered Phase Two, which called for the creation, ventilation, and final approval of a plan to accoinplish necessary desegregation. In so venturing, the court was not exactly pioneering in virgin territory, for courts had been doing this kind of thing for the two decades since Brown v. Board of Education. ${ }^{3}$ Nevertheless, the process is far from standardized and requires the trial judge to do something quite different from proclaiming a right or assigning liability. The judge must find the best way to accomplish a goal, seeking help not only from the parties but from court-appointed experts and masters, and fron citizens' committees. In this case, the district judge was concerned with such things as bus routes and distances, appropriate white-black-other minority ratios for specifie schools, magnet schools, enrichinent prograins, inethods of transfer between schools, teacher recruitnient, and pairings of colleges and universities with specific secondary schools. All of these issues ordmarily would be appropriate grist for the relevant educational policymaking body, here the Boston School Committee. Indeed, the function is very close to legislative decisionmaking. Because the legislative authorities would not act, however, the district judge was forced to nove beyond the traditional judicial role into Phase Three and fashioned his own remedy. ${ }^{4}$

Our task of appellate review found us in strange territory. We first had to determine if the anount of desegregation adopted by the district court was the minimun-and no more-cominanded by the Constitution. Then we were expected to judge whether the district court, assuming the desegregation targets were proper, had chosen the least burdensonie nianner of achieving those targets and a remedy that would remove only that segregation which was attributable to official

1. Morgan v. Hennigan, 379 F. Supp. 410 (D. Mass. 1974).

2. Morgan v. Kerrigan, 509 F.2d 580 (Ist Cir. 1974), cert. denied, 421 U.S. 963 (1975).

3. 347 U.S. 483 (1954).

4. Morgan v. Kerrigan, 401 F. Supp. 216 (D. Mass. 1975). 
actions. The direction of our deference was complicated somewhat because tlie district judge had refused to accept the plan put forward by the masters he liad appointed. We resolved all of these problems by adopting the traditional stance of looking to see if the trial court's plan was supported by the evidence. We held that it was. ${ }^{5}$

Determining liability and framing a plan of desegregation are substantial tasks in themselves. Some judges charged with desegregation missions have been fortunate enough to extricate themselves at this point if the local school autliorities are sufficiently interested in and capable of implementing the desegregation plan. Often, lowever, as im the Boston case until recently, the attitude of the school committee was one of absolute intransigence. The committee would not lave assigned or hired personnel, appointed headmasters, sclieduled buses, ordered the construction or repair of facilities, or even supplied needed equipinent without a court order. The district court thus found itself embarked on Pliase Three in which it set deadlines for registration, ordered the school committee to make necessary contracts and purchases, and even placed a particularly troubled higli school under receivership. At one point, the school committee was found to be im contempt of court, a finding that lan= was withdrawn. During this phase, the district court was domg its best to make the plan work; it was implementimg. In a word, it was perforning the executive function of administration.

This range of activities led to a number of appeals. We became soinewhat used to dealing with cliallenges to the appoimtment of headmasters, the legitimacy of school committee votes "under protest" by order of the court, and the transfer of a football coach. The challenge to the court's imposition of the Soutll Boston High School receivership posed our most novel legal problem. While tlie receivership precedents lay in other fields for the most part, we concluded, on the basis of the rather dramatic record of opposition by scliool officials to any efforts to desegregate and the unpalatable alternative of closing the scliool, that creation of the receivership lay within the proper exercise of the powers of the trial judge. ${ }^{6}$ We also urged, as dictum, that termination of the receivership at the earliest feasible moment should be a constant goal and consideration of the district court. ${ }^{7}$ In sum, part of our reviewthe actual holding-was typical appellate work. But our dictum, setting the stage for noving out of the receivership, was something one ordinarily could frown on as beyond tle proper scope of an opimion.

5. Morgan v. Kerrigan, 530 F.2d 401 (1st Cir. 1975), cert. denied, 426 U.S. 935 (1977).

6. Morgan v. McDonough, 540 F.2d 527 (1st Cir. 1976).

7. Id. at 535. In due time, although almost two years later, attitudes and capability had so changed that the district court felt that it could responsibly terminate the receivership. 
My second example of new model litigation involves the imposing, if obsolete, Dowager of Detention, the Charles Street Jail in Boston. Here again the plaimtiffs are a class of fluctuating membershipnonbailed detainees awaiting trial. Defendants include the county sheriff, the mayor, and the city council. Phase One was trial of the issue of constitutional violation. The district court's judgment that conditions in the jail violated the due process rights of the detainees and that the jail must be closed became final in the absence of an appeal. ${ }^{8}$ The court ordered immediate correction of some problems and ruled that no detainees could be housed in the jail after June 30, 1976. Phase Two consisted of a delay of several years in which literally nothing was accomplished because the defendants-the mayor and the councilcould not agree on a site for a new jail. Near the end of the origmal three-year grace period, the district court postponed the closing for an additional year, until July 1, 1977.

As this new extension began to run out, the court granted an additional extension until November 1, 1977. The district judge also ushered in Phase Three, however, by ordering the defendants to renovate another facility, City Prison, to serve as an interim facility until a long-term solution could be developed. We granted a stay of the portion of the order relatimg to City Prison, but not the closing date. On Noveinber 2, the parties still had no plan ready to implement, largely because of the on-going impasse between the inayor and the city council over whether to build a new prison or try to renovate the old one. The court ordered the council to appropriate funds to use the Middlesex County Courthouse and postponed the closing of Charles Street Jail until five weeks after the appropriation. We stayed this order pending an expedited appeal and lieard argument the first week of Deceinber. Because the parties indicated that there was a good chance of working out a inutually satisfactory plan themselves, we agreed to stay the pending order until March 3,1978, while we kept the appeal under submission. On March 1, the council indicated the lack of agreement by appropriating $\$ 10$ million to renovate the Charles Street Jail, a plan the plaintiffs and the other defendants opposed and which the district court had decided earlier was not feasible.

On March 17, we affirmed the decision to close the jail, but set the date of October 2, 1978. We also ordered the parties to present a plan to the district court by May 1 and urged the district court to pass on the plan by June 15 at the latest. Our opimion instructed the parties (and the court below) exactly what to expect if various contingencies occurred. We took the position that we would not order the city council

8. Inmates of Suffolk County Jail v. Eisenstadt, 360 F. Supp. 676 (D. Mass. 1973). 
and the mayor, or the sheriff, to adopt any particular plan or to appropriate any money for any temporary or permanent facility. We simply ordered the Charles Street Jail closed by a particular date, saying that the only condition for its remaining open on a temporary basis would be a firm, financially adequate commitment to a permanent facility that passed constitutional inuster. ${ }^{9}$ One final controversy was touched off when the council submitted a new plan to renovate Charles Street. The district court refused to evaluate the plan because it was not fully funded. We affirmed the court's refusal, but our order imcluded language encouraging the district court to give early evaluations of good faith, long range plans. ${ }^{10}$

As the deadline approached, the litigation had taken a turn away from the normal adversary contest in which parties can assess the cliances of winning and losmg and gamble on probabilities. Here, if nothing was done, there was no chance of anybody winning anything wortl gambling for: detamees faced housing im ill-suited, makeshift quarters; the city faced a chaotic situation and the ultimate necessity of even more costly facilities; and the public faced the unhappy possibility that the jail in fact would be closed and the detamees set at large. The task of the district court was to attempt to persuade the parties to alter their old, uncompromising, adversary strategies and, while remaining open to reasonable proposals, to be and appear to be resolved to adhere to the deadline. For the reviewing court, thankfully, there ultimately was nothing nore to be done because the parties settled at the eleventh lour on a program of rehabilitatimg the Charles Street Jail with funding set at the realistic level of $\$ 15$ million. Regardless of the outcome of the litigation, it is clear that the district court's role in this drama, and our role as an appellate court, were not the traditional ones of finding facts, making conclusions of law, and reviewing the abuse of discretion or clear error of law. We were working with a different calculus.

\section{III}

\section{The Contrast Between Conventional adjudication AND INSTITUTIONAL REMEDIAL LITIGATION}

The predominant areas into which the courts have been thrust are scliool systems, jails, mental institutions, public universities, police departınents, governance of unions, business reorganizations, and housing projects. What seems to be emerging and enduring is a kind of lawsuit that differs in many facets from conventional adjudication and places different demands on both the trial judge and the reviewing

9. Inmates of Suffolk County Jail v. Kearney, 573 F.2d 98 (1st Cir. 1978).

10. Inmates of Suffolk County Jail v. Kearney, 577 F.2d 761, 764 (1st Cir. 1978). 
court. Here is my catalogue of differences: ${ }^{11}$

The Issue

Parties

Critical facts

Governing Principle Legal precedents.

Taking of evidence

Relief sought

Framing of decree

Impact

Duration of court involvement

Role of Judge

Review
Conventional Adjudication

Likely to be of private rights and duties. If public body involved, issue likely to be procedural.

Likely to be one "person" suing another.

Historical (what has happened) and adjudicative (relevant to rights and habilities of the two parties).

Adversary hearing and rules of evidence.

Declaration, negative imjunction, dainages; normally narrow, closely tied to legal injury.

Imposed by court after hearing evidence.

Confined to parties.

One-time judgment.

Passive: adjudicative in resolving dispute between two parties in a one time, normally self-executing, judginent.

Abuse of discretion and error of law; sufficiency of evidence and legal precedents important.

\section{New Model}

Likely to involve substantive rights and means of compelling a public body to effectuate those rights.

Likely to be a class of individuals suing a class of officials, public institutions, and political entities.

Predictive (situation as it is likely to exist during life of decree) and legislative (relevant to continuing decree).

Strategy, tactics, and potential outcomes not informed by legal precedent.

Wide participation, relaxed standards, more expert opinions.

Affirmative injunction, affecting many beyond parties; potentially broad.

Large amount of negotiation.

Affects a large segment of society.

Continuing decree; subject to reopening and amendment.

Active: legislative in framing criteria; executive in impleunenting decree.

Contribution of appellate court to policy, strategy, and tactics more important than monitoring fact findings or legal principles.

These add up to a significant qualitative difference between conventional adjudication and the new model of litigation. New model litigation generally is brought by a broad class that enjoys wide-ranging discovery and seeks affirmative imjunctive relief from public officials and institutions; under these circumstances the judge must play not only an adjudicative role, but legislative and executive roles as well. It is rare that a few individuals in one branch can find in their normal workday routime a mix of all three major responsibilities of governinent. To the extent that a broad class action results in a wide-ranging affirmative decree, it resembles legislation, but the judicial "mini-legislature" is neither elected nor directly responsive to majoritarian dic-

I1. For a number of these perceptions, I am indebted to Abram Chayes and his article, The Role of the Judge in Public Law Litigation, 89 HARv. L. Rev. 1281, 1302 (1976). 
tates. To the extent that a complex reorganization plan for a school systein or jail is being impleinented, it resembles executive department administration. In carrying out this task, however, the judge-executive lacks the executive's traditional access to the data and expertise of offices, bureaus, agencies, and departments and to a hierarchy designed to translate policy developed at headquarters into programs and projects carried out in the field.

If the functions performed are different, we might ask how well our traditional forms, customs, and practices serve them. I suggest that we suffer froin the defects of our virtues. By this I mean that the very devices that long ago proved themselves invaluable to the adjudicative process now limit the effectiveness of both the trial and appellate courts in fashioning remedies in new inodel hitigation. For example, an independent, self-rehant judge, drawing on the professional disciplines he has perfected over a lifetime, can approach a conventional trial, confident of his capacity to judge credibility, winnow wheat from chaff, find facts, reason logically, and arrive at conclusions of law. As a generalist, he brings a broad perspective to even technical issues. But it is quite a different enterprise to send a sohtary trial judge to hear a choir of experts, review voluminous data, step into the shoes of a social planner and public executive, and devise a long-range, multifaceted public impact program without any guidance or support from an organization.

A second device that impedes the new model at hitigation is the absolute bar to conversations between trial and appellate judges about a case pending decision. This restriction is a necessary prerequisite to the integrity of judicial decisions in the conventional sense. But the task of devising the most effective strategy and tactics to achieve a social goal would not seem to be advanced by barring all exchanges of views on remedy issues by those who share the duty to decide. In reviewing the ordinary adjudicative decision of a trial court, the appellate court is aided by a bundle of tried and true devices, customs, and precepts. It is confined to the cold record and the issues as they have been narrowed by the parties, in harmony with the limited review to be accorded the appellate court. On appeal there are no parties or witnesses to be heard, only the lawyers; agam, this is consistent with the concept that the appellate court's focus is not on overall sense, wisdom, and justice, but rather on egregious judgment in factfinding and legal error. This basic posture of deference to the district court is enninently sound in a syste1n of dispute resolution in which appeal inust be something considerably less than de novo review. Finally, there is a policy against pieceneal appeals. This policy makes sense in the context of 
deciding cases between individuals; slight convenience to the parties is a poor counterweight to excessive burdening of the court.

Each of these conventions of appellate review fares ill, however, when weighed against the deniand of the new wave of public law litigation and its emphasis on broad ranging remedies. It is no longer obvious that the appellate court should be viewed as solely a safety valve of last resort rather than as an active partner in the enterprise of arriving at a sensible reniedial prograin. If appellate courts should not be so viewed, there is little nerit in limiting their access to data contained in the cold record. More importantly, there would seem to be little reason to defer to the judgments of the trial court on remedial matters; the task of fitting together a broad remedial package calls not so much for judginent as to credibility as for experience, wisdom, sense, and intuitionattributes that are not monopolized by the trier-of-fact. As for the ban on piecenieal review, its rationale is diminished in a coinplex remedial undertaking. The entire spirit and pace of the enterprise could be aided significantly by a quick decision of soine important but "interlocutory" decision.

\section{IV}

\section{An Evanescent Phenomenon?}

All of this seenis to ine to describe a serious lack of "fit" between our traditional litigation and review equipinent and our current employnient of those tools. Such a situation inust provoke the most urgent of questions. The first and most human response is to ask whether the problems that necessitated this kind of institutional remedial litigation will not simply go away of their own accord. After all, the numbers of school systenus, jails, universities, and inental hospitals are finite, and many of thein are taking the imitiative to lift the level of their governance. Also, we may hope that legislatures, state and national, will becoine more responsive to the needs of people, more able and willing to deal with issues that today are considered too hot, too antimajoritarian to handle. As younger, broader, more sensitive, and better educated people are elected, this hope gains in prospect of realization. Certainly my hope is that the judiciary, as it continues to cope with this new wave of litigation, does so as part of a healthly trinity in which the other branches also respond creatively and effectively to new conditions.

After indulging in as inuch optimism in this direction as I consider realistic, I conclude that the problems facing courts in devising broad and ongoing remedies will not disappear. With no credentials as a 
futurologist, I nevertheless venture the following predictions of the conditions that are likely to color the remainder of this century:

First, the future is likely to see population (even a fairly stable population) pressing inexorably against limited material resources, energy, and space.

Second, this pressure will be intensified by our continuing expansion of personal demands, aspirations, and expectations.

Third, people increasingly will aspire to "justice-dominated" distribution of resources in short supply. This ineans that they will expect to have access to the forums of decision, equahty of consideration, and fairness of procedures.

Fourth, this will lead to statutes, regulations, and judicial interpretations as the means by which our democratic society will strive to balance competing claims.

Fifth, the result will be that the hitigation of the future is likely to be increasingly class-, structure-, or institution-oriented. Litigation may become a first cousin to single issue politics-it is but a short step from an organization with a mailing hist to a class action seeking judicial relief that previously was demed by the electoral process.

I therefore conclude that the socio-econoinic-politico-cultural-legal ambience of the country is not going to metainorphose benevolently in sucl a way as to allow the judiciary to becoine less of a lightning rod for public controversy. Soine approach other than ignoring the problein is needed.

\section{$\mathrm{V}$ \\ The Challenge to Legitimacy}

Anotlier response to the lack of fit between traditional judicial processes and the new wave of public law litigation is to deny the legitiinacy of courts to fashion prolonged institutional reinedies. One works along; he reads the papers; he thinks; then one day he reads about inucli commotion as the result of a judge's order. And lie suddenly has an inspiration: this is a deinocratic country, yet here are these judges, responsible to no one, ordering these big changes. And so he seeks to release his frustrations by fulminating against the irresponsible judiciary. The truth is that this is not a deinocratic government in the sense that Athens was or a New England town ineeting is. Not every part of our government is popularly elected for a two year tern. The House is, but the President is not, nor is the Senate. The denocratic House can be stymied by the less deinocratic Senate. Both houses can be frustrated by a Presidential veto. The President is, in short, in command of the equivalent of one-third of the votes of a house of Congress. And the judiciary on occasion can veto either an executive order or an act of Congress and do this on behalf of the rights of an individual even 
though the will of the majority is thereby flouted. In turn, Congress can deny the judiciary's request for staff, space, equipment, pay, and allowances. And it has the power to restrict, alter, add to, or subtract from the jurisdiction of the courts.

So each branch has ample scope to run amuck in the vimeyards of the others, knowing that the others have the reciprocal right. Nevertheless, it is very difficult for most Americans to realize that their governinent is not a pure form of democracy, not a pure form of anything. It is, to use a neutral word, a "mixed" form of government-with some scent of aristocracy, some of broad-based democracy, and some of rather remote and indirect democracy. The ambiguity of our system requires that in each generation we reexamine our principles to see whether we still adhere to these difficult propositions-that by and large we are for majority rule, but that we also recognize a substantial number of individual rights; that these rights are dynamic and are growing rather than shrinking; and that we have assigned to our courts the job of defining them and seeing that they are respected.

In our generation, the debate on these propositions is sharpened by the actions of courts in the fleld of institutional remedies we have been discussing. Even scholars sympathetic to the efforts of courts to protect constitutional rights are deeply concerned about judges becoming mired in an open-ended process of attempting to rebuild social and governmental institutions, bypassing the majoritarian processes and bodies that traditionally have been responsible for social and political change, and perhaps striving for rehef far beyond that which is necessary to eliminate constitutional violations. Ultimately, judges may find themselves ordering the other branches of government and often other sovereign states to take actions that require the allocation of scarce funds without regard to the funding priorities of those governments. ${ }^{12}$

Sensitive observers find themselves in a dilemma for, while they are concerued about the vulnerability of the courts and the mtegrity of the majoritarian institutions, they are also keenly aware of some equally sobering considerations. First is the often forgotten fact that repose between courts and other branches and sovereigns is not a realistic goal; tension is built into our system. A second easily overlooked factor is that hitigation about individual constitutional rights does not rise from a vacuum nor is it incited by a court; it arises because there is a problem between an individual or group and an imstitution or governinental unit. Often, as in the Boston School case, the existence of a broad ranging and long enduring constitutional violation is attributable to the intransigence of the imstitutional defendants.

12. For a thoughtful elaboration of these themes, see Professor Paul Mishkin's John Randolph Tucker Lecture: Federal Courts as State Reformers, 35 WASH. \& LeE L. REv. 949 (1978). 
A third relevant observation is that, no matter where the blame for any unconstitutional institutional condition may be lodged, there always exists-or should exist-an opportunity to avoid court-managed reinedies during what $I$ have called Phase Two of the new model litigation. This is the stage following the determination of liability when officials of the affected agency, imstitution, or governmental unit are looked to in the first instance to draw on their expertise and present a suggested solution that embodies their institutional wisdom. This is or ought to be the occasion for defendants, assuming good faith, to regam the initiative. Only after ample and hospitable opportunity has been given to this end and proven sterile should courts consider that the initiative has been thrust back into their hands.

Finally, no inatter how troublesoine the most extreine examples of court-ordered institutional remedy nay be, it is difficult, both conceptually and practically, to draw a sharp boundary delineating the remedial authority of the courts. ${ }^{13}$ From a practical point of view, not only do inost reinedial cases fall far short of the few cases of maximum involveinent by judges, but a large host of institutional cases are satisfactorily and sensitively settled via the consent decree route. Indeed, the reality of the threat of litigation ending im an inposed affirmative decree cannot be discounted as a factor in inducing peaceful and practicable accommodations.

The foregoing discussion of the court's role in institutional remedial litigation is merely an atteinpt to sketch the major fronts visible on the battlefield of legitimacy. Contemporaneously with the ongoing debate as to legitiniacy, however, I argue for an exploration of ways and means of improving the performance of courts in effectuatimg institutional remedies. I know that solne view this with reluctance, feeling that such explorations can only whet the appetites and fuel the fires of judicial activists. But I feel that insights into the possibilities of practice can illumine the propositions of theory. Indeed, I see the exammation of the workability of specific measures as lifting the legitimacy debate out of its well-worn rut of conclusory chiches. To the extent that processes may improve the soundness, participatory nature, and accept-

13. The ancient attempt to distimguish between negative and mandatory injunctions comes to mind. It is by no means true that a negative order will necessarily be less imtrusive than a positive command. The closing of a jail, for example, might well have far greater impact on a community, whether as an indirect spur to raising funds or simply in the direct result of turuing former prisoners out on the streets, than, say, an affirmative order that a prison's law library be upgraded and nuade more accessible. Moreover, the viability of a negative-affirmative decree dichotonyy depends on the nature of the rights at stake. If the imdividual right is itself a negative one-that is, to be free from some specific requirement or burden-it perhaps can be wholly vindicated by preventing some official action. If the mdividual right is a positive one of entitlement to some opportunity, status, or condition, however, it may be capable of realization only by the government or institution undertaking some action. 
ability of court-supervised institutional remedies, this inquiry will bear on any ultimate decision as to the proper scope of court involveinent. If, on the other hand, the most probing effort to explore such possibilities reveals little or nothing of a practical nature that can be done without creating inore probleins than are solved, the ultimate policy decision will have been clarified.

\section{VI \\ AREAS FOR EXPLORATION}

With this apologia, I doff my robe, cast convention aside, and appeal to the spirit of the common lawyer, a conservative enough fellow, but one who on occasion proves his eclectic ability to invent, poach, and patch. One of his number, chafing under the forms of action, imvented an action on the case, a most serviceable tool in its long day. Others discerned the need for soinething called "equity" in addition to "law." In this century we have seen the inspired creation and developInent of administrative law. More recent examples of constructive innovation include the pretrial conference and its inasterful use by some judges, the impressive recourse by soine courts to an omnibus pretrial procedure in criminal cases, the judicial development of the sophisticated techniques that now comprise the Manual for Complex Litigation, and the class action device together with suggestions directed at its improveinent.

\section{A. The Threshold Decision to Consider Broad Affirmative Relief}

After the liability phase has concluded, courts very consciously should satisfy themselves that a rather high threshold requirenent has been met before they roll out the apparatus of broad-based, long continuing, judicially administered remedial action. The objective should be to inake this kind of court involvement, seen by inany as unduly intrusive, be and appear to be a remedy of last resort. Various devices can serve this task. In furtherance of what I have said earlier about the opportunity for defendants to regain the imitiative in Phase Two, a trial court inight well be required to make a supported finding that defendants were offered sufficient guidance, adequate time for preparation, and an unrestricted opportunity to present and justify their proposals. Moreover, the court should specify the nature and extent of any madequacies. Expedited interlocutory review of such a finding also might be advisable.

An alternative approach, also calculated to raise the threshold for intervention, would be to reactivate and adapt the old three-judge court panel-such a device was, after all, originally justified as a ineans of minimizing irresponsible injunctions against the operation of state 
laws. The perceived dangers in both circumstances are analogous. Another safeguard is an analogue of the doctrine of exhaustion of administrative remedies; a local panel might be required to consult with a national and centralized panel of expert judges, whose advice must be sought but would not be binding. A final possibility would be to analogize Phase Two to the cooling-off period enforced im certain labor disputes of wide impact, with mediation services employed $\mathrm{m}$ the interim should they appear to be useful.

Whatever device or procedure is adopted, a delicate balance must be struck to provide defendants the opportunity and mcentive to use it without eroding the rights of plamtiffs that already have been adjudicated worthy of protection.

\section{B. The Composition of the Trial Court}

Since, as we have noted earlier, there may be nothing sacred or even crucial in the concept of the solitary trial judge at the remedial stage, there is rooin to improvise. One possibility would be to empower the trial judge to invite in an outside expert judge with similar experience elsewhere who, without vote, might sit im on hearings and consult. The specter of ex parte discussions or influence would not seem to be of as inuch concern at the remedial stage as when liability is at issue.

An even inore unorthodox step would be to have appellate court participation in the key arguinents. The idea would be that one or two appellate judges would sit in on critical arguments, absorb the atmosphere, gain a better appreciation of the problem, and help imforin the court of appeals so that it could play a more sensitive role. The appellate judge or judges would not participate in the final decision of the district court. Their involvement in the district court hearings would help insure, however, that the trial and appellate courts were operating with the same premises, facts, and objectives.

\section{The Hearing}

The Phase Three remedial hearing would be quite different from the traditional, rigidly structured adversary liearing subject to rigorous evidentiary rules. The objective would be to achieve broad participation and to receive data of any sort that inight be helpful in devising workable solutions. The resources available to the court would mclude not inerely expert consultants and masters, but amici, "absentee advocates," guardians ad litem, and "public counsel."14 Indeed, the availability to the trial judge of a reliable and knowledgeable clearinghouse

14. See Project, The Remedial Process in Institutional Reform Litigation, 78 ColuM. L. REv. 784, 907-09 (1978). 
service through which he could obtain the help of proven experts might save the courts incalculable time and effort and, occasionally, embarrassinent. The kind of inquisitional hearing held by factfinding judges in the civil law system is another possibility. While I would rather entrust the determination of individual rights and liabilities to judges and juries, buttressed by the right of cross-examination and subject to the rules of evidence, I ain not so sure that in the quest for effective remedy we cannot improve our processes by mining the rich lode of the civil law.

\section{The Record}

Facts are used at the remedial stage, not to describe an episode frozen in history, but to shed liglt on the ways to resolve present and future problems. In liglt of this, there would seem to be a need for greater ease in opening the record and reflecting changes in circumstances as they bear on remedies so that orders also may be amended with minimuin difficulty.

\section{E. The Composition of the Appellate Court}

In reviewing district court remedies, the task of the appellate court is to judge them by prudential considerations of strategy and tactics rather than by recourse to our familiar "neutral principles." This is dramatically different from the court of appeals' nornal role. In the light of my suggestions for the composition of trial courts in Phase Three remedial proceedings, it is only logical that I propose the mirror image for the courts of appeals. The district judge should participate at the appellate argument, as either questioner or questionee, and as a resource person for the court of appeals throughout the appellate process. The district judge might well have answers or insights to questions of feasibility, time and money constraints, the willingness of parties to take particular courses of action, and other questions that call for greater immersion in the case than the appellate court can have. This also would give the district court a better understanding of what the appellate court is trying to do.

\section{F. Standards Governing Appeals}

\section{Appealability}

The appellate court, in this kind of case, ought to be able to authorize an interlocutory appeal, if it believed that the speedy resolution of an issue would advance tlie solution of the general problein. Indeed, despite the anathema of the advisory opimion, I can imagine a healthy dialogue taking place on the basis of a nonbinding colloquy. In this 
context, the district court needs to talk to someone; I think that it ought to be able to talk to the appellate court without binding either party. Of course, counsel should be apprised of all such dialogue.

\section{Standard of Review}

Since the strategic and tactical decisions made in institutional cases stand to benefit from consideration by inore heads than one, the reason for the traditional deference accorded the trial judge diminishes. The standard of review might well be more stringent than abuse of discretion. The appellate court should be allowed to hold up a district court decision until the latter considered hitherto overlooked strategies and tactics. The appellate court could use a wide range of standards. If it dealt with a standardized situation, it could prescribe a rule. If not, it could struggle with guidelines. ${ }^{15}$

\section{G. Termination Decisions}

Just as this kind of remedial process might well begin with a heightened threshold requirement, so there should be built-in devices to enhance the prospects of disinvolvement of the courts. I can envisage a judicially designed "Sunset Law" provision that could becoine standard operating procedure, requiring the parties and the court periodically to assess the feasibility of complete or partial withdrawal, at a definite time or in a phased prograin.

\section{CONCLUSION}

As this paper is written, the sluicegates have been raised and a flood of legislation aimed at new structures and procedures for the federal judiciary has reached the shores of the Congress. The proposals include arbitration, the enlargement of the powers of inagistrates, expansion of discretionary Supreme Court review, and abolition of diversity jurisdiction. Merger of the Courts of Clamis and Custoins and Patent Appeals, which would lodge exclusive jurisdiction over patent cases in the new "Court of Appeals for the Federal Circuit," also has been proposed. Otlier proposals would create a Court of Tax Appeals, hberalize transfers between districts and interlocutory appeals, create a Judicial Tenure Commission, and do much, inuch more. ${ }^{16}$ My chief concern is that nobody seems to be worrying constructively over this set

15. For an arguınent for heightened review, calling for appellate court involveinent ranging froun the making of specific rules and guidelines to examination of the decisionınaking process, preferred presumptions, and particularistic review for adequacy and appropriateness, see Hinkle, Appellate Supervision of Remedies in Public Law Adjudication, 4 FLA. ST. U. L. Rev. 411 (1976).

16. See generally S. 678, 96th Cong., 1st Sess. (1979). 
of problems. What we see in the popular press, as we have through all of our history, are polemics agamst individual judges and the judiciary. Our uniquely mixed system of government is both fragile and durable. It is durable, despite its fragility, because it has proven to be flexible when occasion warranted. The polemics hammer away at our fragility; our need is to find new flexibility and resilience to cope with new conditions. 